\title{
Serum ferritin as indicator of iron responsive anaemia in patients with rheumatoid arthritis
}

\author{
TROELS MøRK HANSEN ${ }^{1}$ AND NIELS EBBE HANSEN ${ }^{2}$
}

From the ${ }^{1}$ Department of Rheumatology, Kong Christian X's Hospital 6300 Graasten, and the Department of ${ }^{\infty}$ Medicine, Division of Rheumatology, Hvidovre Hospital, 2650 Hvidovre, Denmark; and the ${ }^{2}$ Department of $\vec{\circ}$ Medicine and Hematology, Gentofte Hospital, 2900 Hellerup, Denmark

SUMMARY In order to test the hypothesis that serum ferritin below $60 \mu \mathrm{g} / \mathrm{l}$ is a good indicator of iron deficiency in patients with rheumatoid arthritis peroral iron was given to 67 patients with जे active rheumatoid arthritis over a three month period. A rise in haemoglobin concentration was if taken as evidence of iron responsive anaemia. In anaemic patients serum ferritin below $60 \mu \mathrm{g} / \mathrm{l} \stackrel{\mathscr{\odot}}{\circ}$ was a good indicator of iron responsive anaemia, with a predictive value of $83 \%$. Although high 윽 plasma transferrin and low mean cell volume showed similar predictive values, more patients $\overrightarrow{ }$ with iron deficiency anaemia could be diagnosed by serum ferritin measurements than by other $气$ conventional blood tests. In contrast, the predictive value of serum ferritin above $60 \mu \mathrm{g} / \mathrm{l}$ was low $(50 \%)$. The test was of no predictive value in non-anaemic patients. In patients with anaemia and active rheumatoid arthritis serum ferritin is the best blood test currently available for the prediction of iron responsive anaemia.

Key words: iron deficiency.

In patients with active rheumatoid arthritis (RA) anaemia may be caused by the 'anaemia of chronic disorders' and iron deficiency. The differential diagnosis between these two types of anaemia is potentially important but may be extremely difficult unless bone marrow smears stained for iron are examined. The main reason for the difficulty is that the usual blood tests indicating iron deficiency (mean cell volume (MCV), mean corpuscular haemoglobin concentration (MCHC), serum iron) are affected similarly in the two types of anaemia. The magnitude of the problem is due to the fact that practically all patients with RA of a certain disease activity develop the anaemia of chronic disorders and up to $75 \%$ of the same patients also have iron deficiency. ${ }^{12}$

Serum ferritin is a good indicator of iron stores in the organism and is valuable in the diagnosis of iron deficiency anaemia. Since it is also an acute phase reactant it might a priori be of dubious value in RA.

In a previous study we showed that in patients with anaemia and RA serum ferritin levels below 60

Accepted for publication 11 December 1985.

Correspondence to Dr Troels Mørk Hansen, Kong Christian X's Hospital, DK-6300 Graasten, Denmark. $\mu \mathrm{g} / \mathrm{l}$ indicated iron deficiency, as assessed by bone marrow examination, better than any other conventionally used blood test (MCV, MCHC, serum iron, plasma transferrin) ${ }^{3}$ Similar results have been reported by others. ${ }^{1} 24 \quad 5$

The present study was undertaken to examine if serum ferritin in patients with RA could predict which patients would respond to iron therapy with a rise in haemoglobin $(\mathrm{Hb})$ concentration.

\section{Materials and methods}

Ninety one patients from the Department of Rheumatology, Hvidovre Hospital, who all had N classical or definite RA according to the criteria $N$ of the American Rheumatism Association were $\mathrm{N}$ treated with iron. Informed consent was obtained $\omega$ from all patients and approval obtained from the local ethical committee.

In 67 patients iron therapy was continued for the entire three months and laboratory values obtained before and after the therapy. There were 52 women and 15 men. Their ages ranged from 22 to 87 years $\frac{\text { Pे }}{D}$

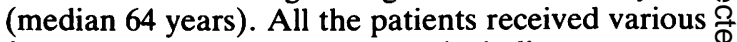
forms of antirheumatic therapy, including treatment $\varrho$ with disease modifying drugs. No patients had르 
manifest bleeding or received blood transfusions during the study.

All patients received ferrous sulphate tablets equal to $200 \mathrm{mg}$ of iron daily The iron was given irrespective of the presence of anaemia. Twenty five women and 10 men were anaemic at the start of the treatment, while 27 women and five men had $\mathrm{Hb}$ within the normal range.

Laboratory investigations before and after three months of iron therapy included $\mathrm{Hb}, \mathrm{MCV}, \mathrm{MCHC}$, serum iron, plasma transferrin, erythrocyte sedimentation rate (ESR), and $C$ reactive protein (CRP) in serum according to routine practice at the hospital laboratory. Serum ferritin was measured with a radioimmunoassay kit from Clinical Assays, Cambridge, Mass., USA; the coefficient of variation was $8 \%$

A Student's $t$ test, Fishers's test, and Spearman's correlation test were used for the statistical analyses.

\section{Results}

The predictive values of the laboratory variables for changes in $\mathrm{Hb}$ in anaemic patients are given in Table 1; all changes in $\mathrm{Hb}$ were included. Serum ferritin $<60 \mu \mathrm{g} / \mathrm{l}$ predicted an increase in $\mathrm{Hb}$ during iron therapy in $83 \%(19 / 23)$ of the patients, while $\mathrm{Hb}$ decreased in $50 \%(6 / 12)$ of the patients with serum ferritin $\geqslant 60 \mu \mathrm{g} / \mathrm{l}(\mathrm{p}<0 \cdot 01)$. In non-anaemic patients serum ferritin had no predictive value. $\mathrm{Hb}$ increased in $61 \%(11 / 18)$ of the patients with serum ferritin $<60 \mu \mathrm{g} / \mathrm{l}$ and decreased in $40 \%(4 / 10)$ of patients with serum ferritin $\geqslant 60 \mu \mathrm{g} / 1(\mathrm{p}>0.05)$. In four patients with serum ferritin $<60 \mu \mathrm{g} / \mathrm{l}$ the $\mathrm{Hb}$ was unchanged during iron therapy.

The results from the individual patients are given in Tables $2 \mathrm{a}, \mathrm{b}$, and $\mathrm{c}$. In Table 3 are given the group means and SEM. There was no difference in serum ferritin between anaemic and non-anaemic patients, but serum ferritin increased during iron therapy. In the anaemic patients $\mathrm{MCHC}$, serum iron, and plasma transferrin were lower than in non-anaemic patients, and ESR and CRP were higher. During iron therapy there was a decrease in plasma transferrin in both anaemic and non-anaemic patients. There was no change in the overall disease activity as judged by an unchanged ESR and CRP during the three months.

\section{Discussion}

This study has shown that in anaemic patients with RA serum ferritin levels below $60 \mu \mathrm{g} / \mathrm{l}$ indicate iron responsive anaemia with a rather high degree of accuracy $(83 \%)$. Although MCV and plasma transferrin scored comparably high percentages, it is evident from Table 1 that serum ferritin would diagnose more patients with iron deficiency anaemia than any other blood test. If the simultaneous presence of low serum ferritin and high plasma transferrin were taken as evidence of iron deficiency anaemia, the predictive value would be further increased (to $91 \%$ ), but again with a loss of the number of patients correctly defined as having iron deficient anaemia. None of the tests were of any value in predicting a negative response to iron therapy, and although low serum ferritin levels were found in several patients in the non-anaemic group, the predictive value was too low to be of any clinical value in predicting a rise in $\mathrm{Hb}$ concentration in this group of patients.

These results support our previous data which showed that serum ferritin was a good indicator of iron deficiency as assessed by bone marrow examination and further defined the clinical applicability of this blood test in terms of its ability to predict iron responsive anaemia in these patients. ${ }^{3}$ These results and those reported by others ${ }^{2}{ }^{4}$ show that serum ferritin is the best blood test for evaluating the iron status in patients with RA. It needs to be considered whether it should replace bone marrow examination in this context.

It is not completely clear why serum ferritin values above $60 \mu \mathrm{g} / \mathrm{l}$ could not predict a negative

Table 1 The predictive values of laboratory variables for a rise or decrease in $H b$ during iron therapy in anaemic patients with rheumatoid arthritis

\begin{tabular}{|c|c|c|c|}
\hline $\begin{array}{l}\text { Predictive value of an abnormal } \\
\text { test ( } \mathrm{Hb} \text { increase) }\end{array}$ & & $\begin{array}{l}\text { Predictive value of a normal test } \\
\text { (Hb decrease })\end{array}$ & \\
\hline $\begin{array}{l}\text { Serum ferritin }<60 \mu \mathrm{g} / 1 \\
\text { Serum iron }<9 \mu \mathrm{mol} / 1 \\
\text { Plasma transferrin }>36 \mu \mathrm{mol} / 1 \\
\mathrm{MCV}<80 \mathrm{fl} \\
\mathrm{MCHC}<19.0 \mathrm{mmol} / \mathrm{l}\end{array}$ & $\begin{array}{r}19 / 23=83 \% \\
20 / 28=71 \% \\
12 / 14=86 \% \\
5 / 6=83 \% \\
9 / 13=69 \%\end{array}$ & $\begin{array}{l}\text { Serum ferritin } \geqslant 60 \mu \mathrm{g} / 1 \\
\text { Serum iron } \geqslant 9 \mu \mathrm{mol} / 1 \\
\text { Plasma transferrin } \leqslant 36 \mu \mathrm{mol} / \mathrm{l} \\
\mathrm{MCV} \geqslant 80 \mathrm{fl} \\
\mathrm{MCHC} \geqslant 19.0 \mathrm{mmol} / \mathrm{l}\end{array}$ & $\begin{aligned} 6 / 12 & =50 \% \\
2 / 7 & =29 \% \\
8 / 20 & =40 \% \\
9 / 28 & =32 \% \\
6 / 21 & =29 \%\end{aligned}$ \\
\hline
\end{tabular}




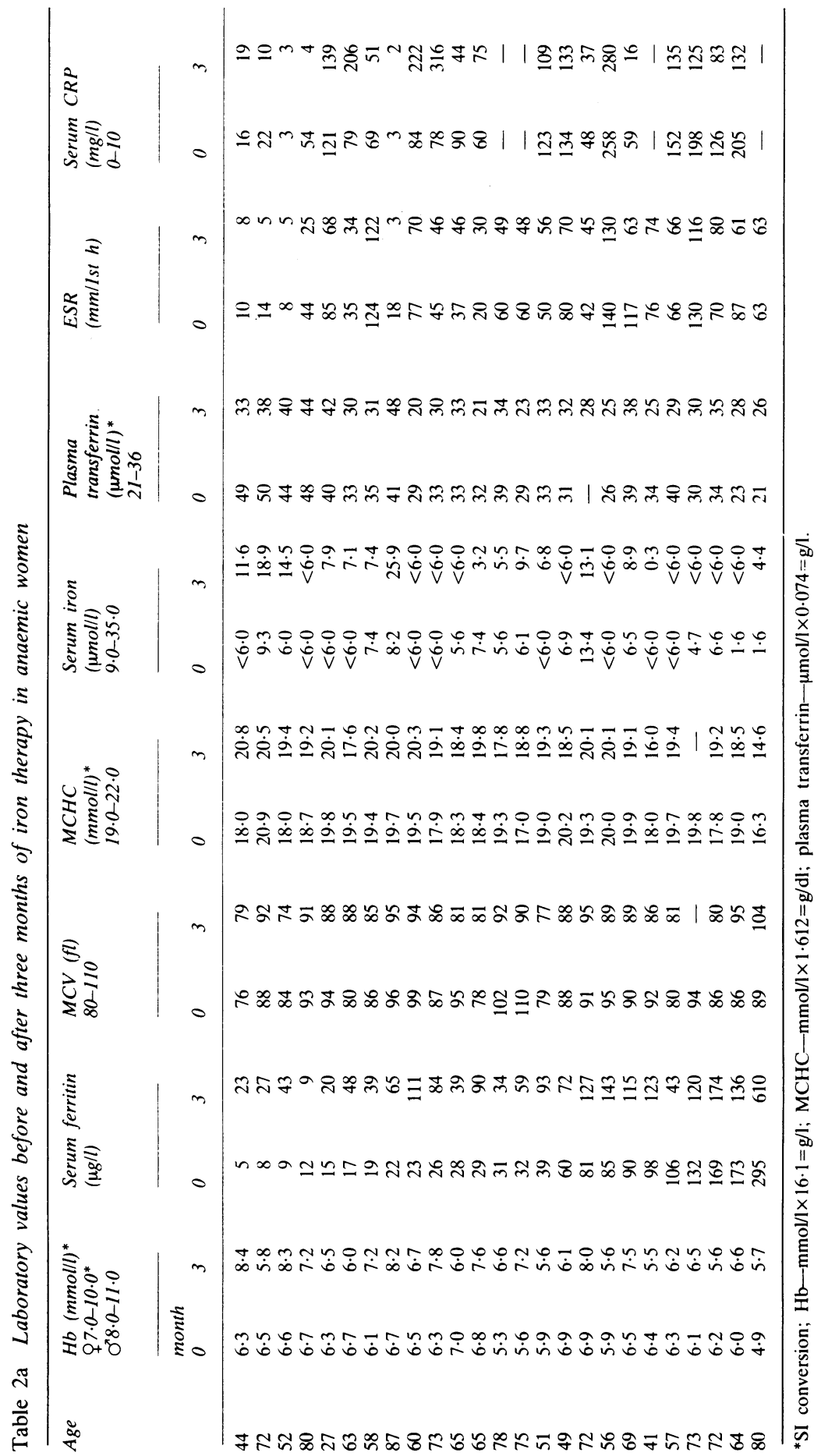




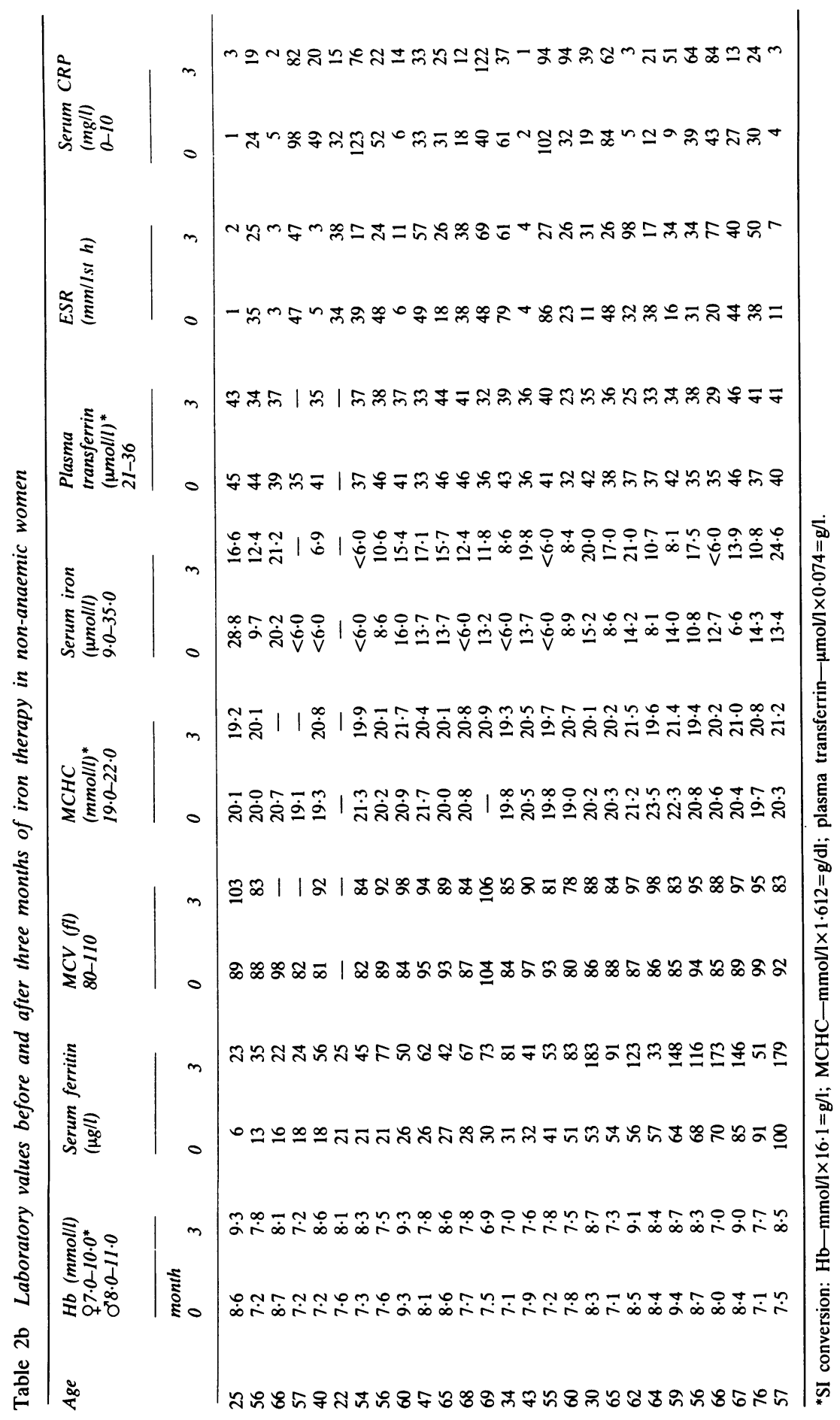




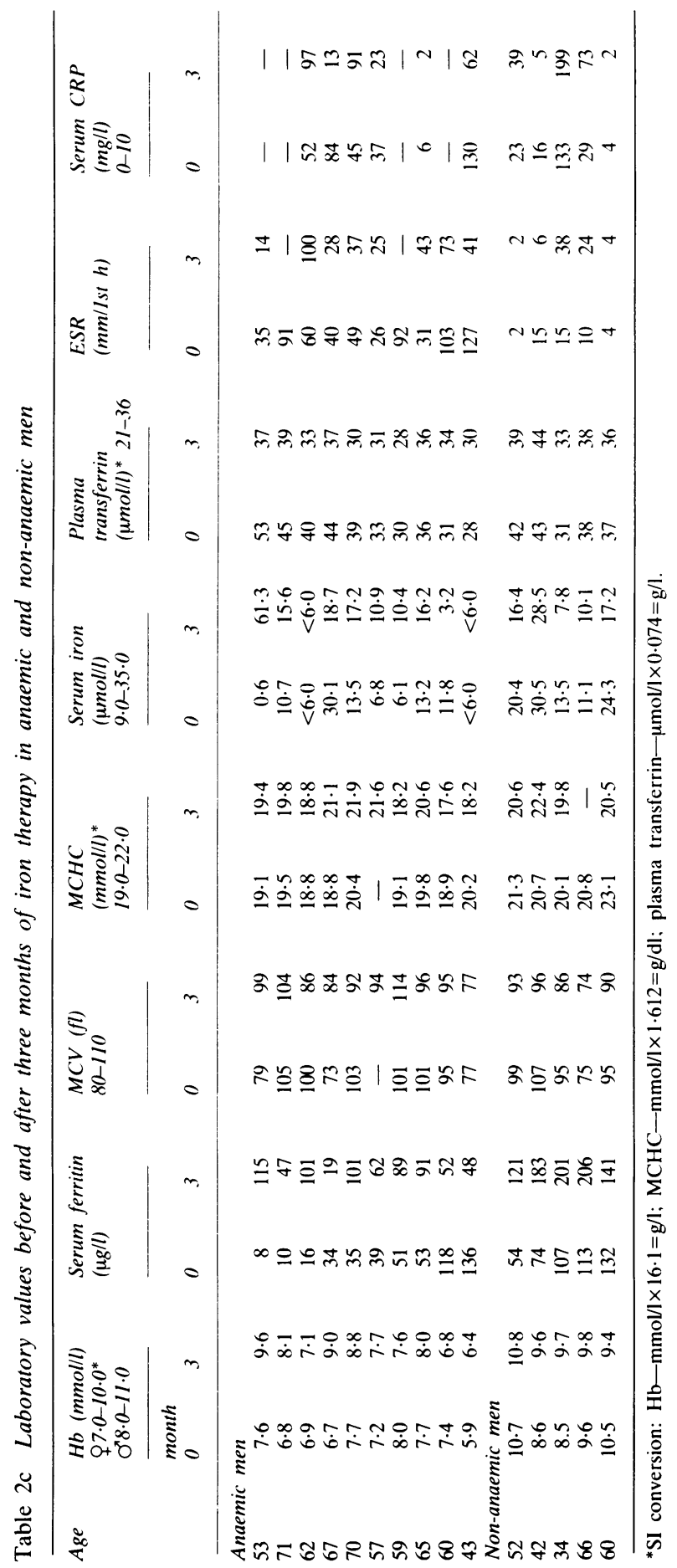


Table 3 Laboratory values before and after three months of iron therapy*

\begin{tabular}{|c|c|c|c|}
\hline & $\begin{array}{l}\text { Before iron } \\
\text { therapy }\end{array}$ & & $\begin{array}{l}\text { After three months of } \\
\text { iron therapy }\end{array}$ \\
\hline \multicolumn{4}{|l|}{ Hb females $(\mathrm{mmol} /)^{\prime}$} \\
\hline anaemic & $6.3 \pm 0 \cdot 1$ & $\ddagger$ & $6 \cdot 8 \pm 0 \cdot 2$ \\
\hline non-anaemic & $\$ 7 \cdot 9 \pm 0 \cdot 1$ & & $\$ 8 \cdot 1 \pm 0 \cdot 1$ \\
\hline \multicolumn{4}{|l|}{$\mathrm{Hb}$ males $(\mathrm{mmol} / \mathrm{l})^{\circ}$} \\
\hline anaemic & $7 \cdot 2 \pm 0 \cdot 2$ & & $7 \cdot 9 \pm 0 \cdot 3$ \\
\hline non-anaemic & $\$ 9 \cdot 6 \pm 0.5$ & & $\$ 9 \cdot 9 \pm 0 \cdot 2$ \\
\hline \multicolumn{4}{|l|}{ Serum ferritin $(\mu \mathrm{g} / \mathrm{l})$} \\
\hline anaemic & $60 \pm 11$ & & $91 \pm 16$ \\
\hline non-anaemic & $50 \pm 6$ & $\ddagger$ & $92 \pm 10$ \\
\hline \multicolumn{4}{|l|}{$\mathrm{MCV}(\mathrm{fl})$} \\
\hline anaemic & $90 \pm 2$ & & $89 \pm 1$ \\
\hline non-anaemic & $90 \pm 1$ & & $90 \pm 1$ \\
\hline \multicolumn{4}{|l|}{$\mathrm{MCHC}(\mathrm{mmol} / \mathrm{l})$} \\
\hline anaemic & $19 \cdot 1 \pm 0 \cdot 2$ & & $19 \cdot 2 \pm 0 \cdot 3$ \\
\hline non-anaemic & $\$ 20 \cdot 6 \pm 0 \cdot 2$ & & $\$ 20 \cdot 5 \pm 0 \cdot 1$ \\
\hline \multicolumn{4}{|l|}{ Serum iron $(\mu \mathrm{mol} / \mathrm{l})$} \\
\hline anaemic & $8 \cdot 2 \pm 1 \cdot 2$ & & $13 \cdot 0 \pm 2 \cdot 5$ \\
\hline non-anaemic & $\$ 14 \cdot 6 \pm 1 \cdot 2$ & & $14 \cdot 8 \pm 1 \cdot 1$ \\
\hline \multicolumn{4}{|l|}{$\begin{array}{l}\text { Plasma transferrin } \\
(\mu \mathrm{mo} / \mathrm{l})\end{array}$} \\
\hline anaemic & $36 \pm 1$ & $\doteqdot$ & $32 \pm 1$ \\
\hline non-anaemic & $\$ 39 \pm 1$ & $\ddagger$ & $\$ 36 \pm 1$ \\
\hline \multicolumn{4}{|l|}{$\operatorname{ESR}(\mathrm{mm} / 1 \mathrm{st} \mathrm{h})$} \\
\hline anaemic & $63 \pm 6$ & & $53 \pm 7$ \\
\hline non-anaemic & $\$ 28 \pm 4$ & & $\$ 30 \pm 4$ \\
\hline \multicolumn{4}{|l|}{$\mathrm{CRP}(\mathrm{mg} / \mathrm{l})$} \\
\hline anaemic & $87 \pm 12$ & & 9()$\pm 17$ \\
\hline non-anaemic & $\$ 37 \pm 6$ & & $\$ 42 \pm 8$ \\
\hline
\end{tabular}

*Values are mean \pm SEM.

SI conversion: $\mathrm{mmol} / \mathrm{l} \times 16 \cdot 1=\mathrm{g} / \mathrm{l}$.

p $<0.05$ for difference between before and after iron therapy.

${ }^{\$} \mathrm{p}<0.05$ for difference between anaemic and non-anaemic patients.

outcome of iron therapy. It must be appreciated, however, that the reference value used in this work, viz a rise in $\mathrm{Hb}$ concentration after iron therapy, may not be quite fair to the test, since a change in disease activity during the three months of iron treatment may also influence the $\mathrm{Hb}$ concentration in the individual patients. Actually, in five of the six patients who in spite of high serum ferritin values showed an increase in $\mathrm{Hb}$ concentration (data are missing for the sixth patient) disease activity decreased as judged from decreasing values for CRP, and consequently the recording of these patients as a failure regarding the predictive value of a high serum ferritin for no $\mathrm{Hb}$ response to iron therapy may not be correct. The strength of the design of this study is that it was shown that a low serum ferritin value could predict a positive outcome of iron therapy despite the presence of confounding factors influencing the $\mathrm{Hb}$ concentration in these patients.

Seventy five per cent of the anaemic patients and
$50 \%$ of the non-anaemic patients showed a rise in $\mathrm{Hb}$ concentration after three months of iron therapy, and $87 \%$ of all patients showed an increase in serum ferritin values. Also a significant decrease in plasma transferrin values after treatment was noted (Table 3). This indicates that functional iron deficiency and iron deficiency anaemia were extremely common in our patients, in agreement with previous experience. ${ }^{1-3}$ It also indicates that peroral iron is readily absorbed in these patients, despite the simultaneous presence of the anaemia of chronic disorders, which is believed to be associated with a decrease of iron absorption from the intestines. ${ }^{6}$ The fact that no test could predict which of the nonanaemic patients would show an increase in $\mathrm{Hb}$ concentration is probably due to the fact that iron deficient erythropoiesis was not prominent in these latter patients. Thus they had normal values for $\mathrm{MCV}$ and MCHC and no significant increase in $\mathrm{Hb}$ concentration after treatment (Table 3).

This interpretation of our finding is not necessarily at variance with that of Bentley and Williams, who demonstrated a transient rise in $\mathrm{Hb}$ after parenteral iron treatment of patients with RA and anaemia. ${ }^{7}$ They suggested that patients with RA may, as a rule, not be iron deficient, but that a relative iron deficiency in the bone marrow may exist due to excessive entrapment of iron in the inflamed synovial membrane.

In our previous study we found no correlation between serum ferritin and plasma fibrinogen, and in the present study no correlation between serum ferritin and CRP could be shown. It thus seems quite well documented that serum ferritin is not a conventional acute phase reactant, though it is increased in active RA per se. These findings constitute the basis for our proposal that serum ferritin levels below $60 \mu \mathrm{g} / \mathrm{l}$ may be used as a cut off point indicating iron deficiency in patients with RA regardless of the disease activity. This value is five times higher than the usual lower limit of serum ferritin indicating iron deficiency. ${ }^{8}$ The peculiar role of serum ferritin, which is increased in active disease but does not follow the conventionally used parameters of disease activity, calls for further studies of the pathophysiology of serum ferritin in active RA.

\section{References}

1 Smith R J. Davis P. Thomson A B R. Wadsworth L D. Fackre $P$. Serum ferritin levels in the anemia of rheumatoid arthritis. $J$ Rheumatol 1977; 4: 389-92.

2 Rajapakse C N A. Holt P J L. Perera B S. Heberden Society, Clinical meeting. June 1980. Ann Rheum Dis 1980: 39: 596-610.

3 Hansen T M. Hansen N E. Birgens H S. Holund B. Lorenzen I. 
Serum ferritin and the assessment of iron deficiency in rheumatoid arthritis. Scand J Rheumatol 1983; 12: 353-9.

4 Blake D R, Waterworth R F, Bacon P A. Assessment of iron stores in inflammation by assay of serum ferritin concentrations. Br Med J 1981; 283: 1147-8.

5 Bentley D P, Williams P. Serum ferritin concentration as an index of stage iron in rheumatoid arthritis. J Clin Pathol 1974; 27: $786-8$
6 Boddy K, Will G. Iron absorption in rheumatoid arthritis. Ann Rheum Dis 1969; 28: 537-40.

7 Bentley D P. Williams P. Parenteral iron therapy in the anaemia of rheumatoid arthritis. Rheumatol Rehabil 1982; 21: 88-92.

8 Jacobs A, Miller F, Worwoos M, Beamish M R, Wardrop C A. Ferritin in the serum of normal subjects and patients with iron deficiency and iron overload. $\mathrm{Br}$ Med $J$ 1972; iv: 206-8. 